УДК 657.471

DOI: https://doi.org/10.36910/6775-2313-5352-2019-14-9

Григор'сва Н.С., д.т.н., проф., Шабайкович В.А., д.т.н., проф.

Луцький національний технічний університет

\title{
ТЕХНІЧНА ПІДГОТОВКА АВТОМАТИЧНОГО СКЛАДАННЯ ПРИЛАДІВ
}

Правильна технічна підготовка (ТП) значно скорочуе час і витрати складального виробництва шляхом аналізу та синтезу структури необхідних робіт з метою їх мінімізації. При иьому вимагається застосування інноваційного підходу комп'ютерно-інтегрованого виробництва СІМ. Завданням $є$ одержання зоптимізованого календарного плану ТП, побудованого з використанням спеціальних алгоритмів і програм, наприклад типу Форда. Для правильного вирішення задачі краще застосовувати автоматизовані системи ТП. Критерієм вибирається показник підготовленості виробу до автоматичного складання, одержаного за інтегрованою методикою такої оиінки.

Ключові слова: складання, підготовка, алгоритм, програма, оцінка.

Вступ.

ТП складального виробництва являється першою та фундаментальною частиною виробничого процесу, від якого залежать техніко-економічні показники виготовлення приладів. Час ТП характеризує календарний період часу, протягом якого виконуються всі необхідні роботи, пов'язані 3 підготовкою автоматичного чи автоматизованого складання. Для забезпечення випуску приладів необхідно встановити необхідну інформацію, потрібні складальні процеси, а також враховувати додаткові процеси, бажані виходи, їх етапи, види діяльності, потоки, контрольні вимірювання, потреби в підготовці складального обладнання, методи, матеріали і інші ресурси [1].

Викладення основного матеріалу.

ТП розділяється на конструкторську, технологічну, організащійну і складається з ряду етапів, підетапів робіт. Конструкторська підготовка (КП) включає розробку: технічного завдання на проектування приладу та технічної пропозиції, ескізного, технічного та робочого проектів, виготовлення та випробування дослідних зразків, запуск в серійне виробництво. Об'єктами КП $є$ як складальні прилади, так і автоматичне складальне обладнання 3 оснащенням, а загалом, конструкція складального об'єкту.

Технологічна підготовка (ТехП) включає: забезпечення технологічності конструкції складального приладу та автоматичного складального обладнання з оснащенням, проектування технологічних процесів автоматичного складання приладів і засобів оснащення складального виробництва.

Організаційна підготовка передбачає: вибір типу виробництва, складальної структури і проектування складальних процесів, організація складальних процесів в часі, проектування системи технічного обслуговування, форм організації та оплати праці.

Зразкова структура технічної підготовки виробництва нового приладу приведена на рис. 1. На структуру впливають: різновид приладу, рівень його сучасності, складність, програма випуску, тип і організаційна форма складання, точність складання та інші показники якості, кваліфікація обслуговуючого персоналу, у тому числі складальників, технічний рівень фірми, цикл технічної підготовки, що закладається, фінансове забезпечення і багато що інше.

Конструкція складального з'єднання повинна:

- максимально відповідати особливостям автоматичного складання;

-забезпечувати складання деталей простими досягненнями при мінімальному числі напрямків складання;

-складатися з максимально можливого числа стандартних і уніфікованих деталей;

- забезпечувати точність методом повної взаємозамінності та виключати необхідність виконання пригоночних і складально-розбірних робіт; 


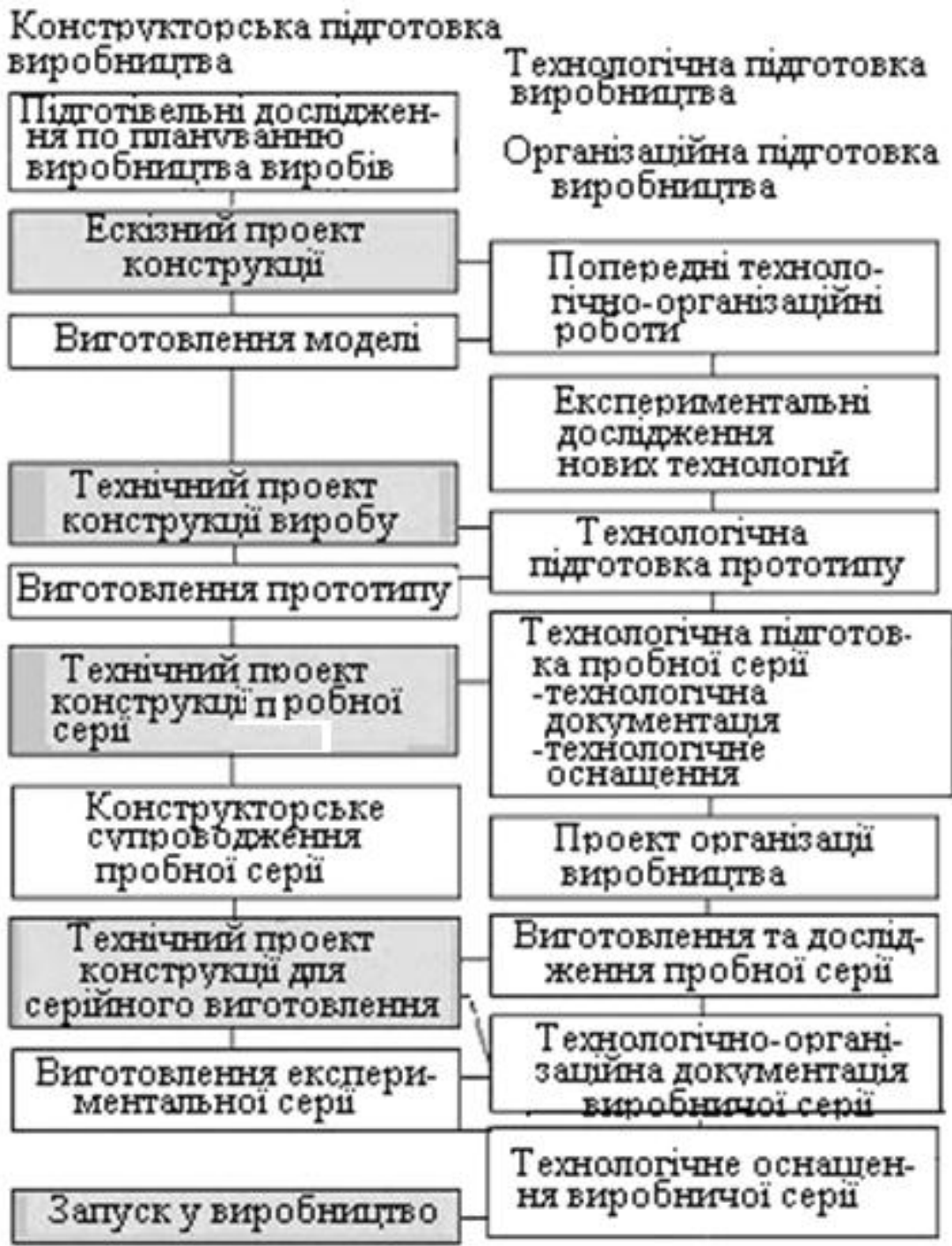

Рис. 1. Схема структури та роботи при ТП виробництва
- складатися 3 мінімального числа деталей iз забезпеченням ix мінімальності за рахунок ускладнення конструкції;

- мати базову деталь i можливість поєднання іii конструкторських, технологічних

вимірювальних баз;

- мати яскраво виражені базові поверхні, що фіксують елементи, а також відповідні направляючі елементи для полегшення автоматичної складальності;

- використовувати нові ефективні методи з'єднання в порівнянні 3 традиційними;

- забезпечувати зручність контролю параметрів складання із застосуванням найпростіших, ефективніших способів i засобів автоматичного контролю.

\section{Оцінка}

технологічності

конструкції автоматично складаних приладів може бути якісною або кількісною. Кількісна оцінка конкретніша,

обгрунтована й забезпечує можливість виконання ефективного відпрацювання технологічності 3 метою досягнення iї оптимального рівня. Методика такого відпрацювання виходить 3 схеми послідовності визначення комплексного показника технологічності конструкції приладу i полягає в розрахунку складових і комплексного показника технологічності конструкції.

Все різноманіття показників технологічності конструкції розбивається на наступні групи:

- технологічної раціональності конструкції приладу (коефіцієнти складності конструкції, складуваності, легкозйомності складових частин, доступності місць обслуговування і т.п.);

- спадкоємності конструкції приладу (коефіцієнти новизни конструкції, вживаності уніфікованих або стандартних складових частин, повторюваності складових частин, типізації конструкційного виконання і т.д.);

- виробничої технологічності (показники трудомісткості виробу в технічній підготовці виробництва, у виготовленні, тривалості технічної підготовки виробництва приладу, тривалості його виготовлення, технологічної собівартості приладу в ТехП виробництва, у виготовленні і т.п.);

- експлуатаційної технологічності (показники трудомісткості приладу в експлуатації, в технічному обслуговуванні, матеріаломісткості приладу в експлуатації, технологічній собівартості в експлуатації і т.д.);

- ремонтної технологічності (показники трудомісткості приладу в ремонті, матеріаломісткості приладу в ремонті, технологічній собівартості в ремонті і т.д.);

- загальної технологічності (показники питомої трудомісткості приладу, матеріаломісткості, технологічної собівартості і т.д.).

(С Григор'сва Н.С., Д.т.н., проф., Шабайкович В.А., д.т.н., проф. 
В процесі розробки приладів і відпрацювання на технологічність конструкції виконується порівняння за базовими показниками, які застосовуються в якості вихідних. Склад базових показників і їх оптимальні значення звичайно встановлюються стандартами або беруться по визнаному перспективному зразку [2].

Методика оцінки підготовленості конструкції приладу до автоматичного складання полягає в наступному:

- Визначаються часткові показники технологічності конструкції складаної деталі за підготовленістю до автоматичного просторового орієнтування, переміщення на складальну позицію, базування на складальній позиції, взаємного орієнтування, спряження та закріплення. Вибір часткових показників проводиться за таблицями, а також можливо i експертним методом.

- Визначаються часткові показники технологічності конструкції складаної деталі, що враховують конструкційні особливості приладу. Це показники технологічності конструкції з'єднання, числа напрямків складання, що входять в нього деталей і вузлів, складності автоматичного контролю. Вони також визначаються подібно вищезгаданим, але враховується ще частковий коефіцієнт вагомості.

По окремим видам розраховуються комплексні показники технологічності:

$$
K_{j}^{k}=\frac{\sum_{1}^{x} K_{i} \alpha_{i}}{\sum_{1}^{x} \alpha_{i}},
$$

де $a_{i}$ - коефіцієнти вагомості; $K_{i}$ - складові коефіцієнти або показники; $x$ - число складових коефіцієнтів. Найменування складових показників вказані в таблицях. Визначається два таких комплексних показника технологічності: конструкції складаних деталей та приладу в цілому.

Розраховується значення комплексного показника технологічності конструкції приладу. При цьому максимальне значення показника рівне одиниці, а мінімальне - нулю. Якщо одержане значення більше 0,85 , то можна вважати, що прилад повністю підготовлений до автоматичного складання, яке може бути здійснена без зміни конструкції складаного приладу. При розрахунковому значенні цього коефіцієнта, що знаходиться в межах 0,35 - 0,85 прилад не готовий до автоматичного складання і вимагається виконати деякі зміни його конструкції або використати іншу технологію складання. При значенні цього коефіцієнта менше 0,5 , можна вважати, що конструкція приладу непридатна для автоматичного складання, а iї проведення практично недоцільне. В цьому випадку потрібна корінна переробка конструкції приладу і зміна технології складання [3].

До недоліків ТП в приладобудуванні можна віднести негативний вплив внутрішніх і зовнішніх чинників, основними з яких можна вважати наступні. Бізнес-чинник: необгрунтоване скорочення необхідних підготовчих робіт, а особливо витрат, що приводить до зниження якості приладів і їх конкурентоспроможності. Перетворення приватизації в «прихватизацію», занепад економіки країни, значний політичний вплив замість економічного. Всі хочуть заробляти гроші прямо 3 повітря. До внутрішніх чинників в першу чергу можна віднести відсутність кваліфікованих розробників, матеріально-технічну незабезпеченість виробництва, замкнутий цикл ТП, неповне використання комплексних стандартів, відсутність між виробничих зв'язків, дубляж питань тощо.

\section{Висновки.}

Більшість приладів приладобудування орієнтована на ручне складання і тому зовсім непридатне для автоматичного. Це вимагає переконструювання як старих конструкцій, так $\mathrm{i}$ проектування нових. При цьому доцільно використовувати автоматизовані системи ТП і їх програми автоматизованого складання, як наприклад програму Forda. Побудова календарного плану робіт складається 3 наступних етапів: конструкторського, технологічного та організаційного. Основною вимогою етапів є одержання плану виконуємих робіт максимально коротким за часом і особливо затрачуваними витратами, що забезпечується комплексною їх оптимізацією.

\section{Інформаційні джерела:}

1. Божидарнік В.В., Григор'єва Н.С., Шабайкович В.А. Автоматичне складання виробів: Луцк. «Надстир'я». 2005. -386 с. 
2. Машинобудування: Енциклопедія. Технологія складання в машинобудуванні. T III-5. / Під заг.ред. Ю.М. Соломенцева. М.: Машинобудування, 2001. -640 с. іл.

3. Григор'єва Н.С. Науково-технологічні основи гнучкого модульного автоматичного складання виробів. - Луцьк. «Надстир'я». 2008. -520 с.

Григорьева Н.С., д.т.н., проф., Шабайкович В.А., д.т.н., проф.

Луцкий национальный технический университет

\section{ТЕХНИЧЕСКАЯ ПОДГОТОВКА АВТОМАТИЧЕСКОЙ СБОРКИ ПРИБОРОВ}

Правильная техническая подготовка (ТП) значительно сокращает время и затраты сборочного производства путем анализа и синтеза структуры необходимых работ с иелью их минимизачии. При этом требуется применение инноваџионного подхода компьютерноинтегрированного производства СИМ. Задачей является получение соптимизованого календарного плана ТП, построенного с использованием специальных алгоритмов и программ, например, Форда. Для правильного решения задачи лучше применять автоматизированные системь ТП. Критерием выбирается показатель подготовленности изделия до автоматизированной сборки, полученной по интегрированной методике такой оценки.

Ключевые слова: сборка, подготовка, алгоритм, программа, оченка.

\section{N. Grigorieva, DSc, PhD prof., V. Shabaykovich, DSc, PhD Prof.}

Lutsk National Technical University

\section{TECHNICAL PREPARATION AUTOMATIC ASSEMBLY OF DEVICES}

Proper technical training (TT) significantly reduces the time and cost of assembly production by analyzing and synthesizing the structure of the necessary works in order to minimize it. This requires the use of an innovative approach to computer-integrated production (CIM). The task is to obtain a optimized calendar plan for TT, built using special algorithms and programs, for example of Ford. For the correct solution of the problem, it is better to use automated TT systems. The criterion is the indicator of the product readiness to the automated assembly, obtained by the integrated method of such an assessment.

Keywords: assembly, preparation, algorithm, program, evaluation. 